Check for updates

1 University of Nottingham, Nottingham, UK

2 University of Manchester, Manchester, UK

3 De Montfort University, Leicester, UK

Correspondence to: $\mathrm{H}$ Sewell Herb.Sewell@nottingham.ac.uk

Cite this as: BMJ 2020;370:m2722 http://dx.doi.org/10.1136/bmj.m2722 Published: 09 July 2020

\section{Vaccines, convalescent plasma, and monoclonal antibodies for covid-19}

\author{
We have good reason to be cautious about these high profile options \\ Herb F Sewell, ${ }^{1}$ Raymond M Agius, ${ }^{2}$ Denise Kendrick, ${ }^{1}$ Marcia Stewart ${ }^{3}$
}

The devastating pandemic caused by the SARS-CoV-2 coronavirus appears to be a prime candidate for traditional prevention (vaccines) and passive immunity approaches. Passive immunity, using convalescent plasma from recovered patients or monoclonal antibodies with high levels of neutralising antiviral activity, have potential for both therapy and prevention.

Worldwide, many covid-19 vaccines are at various phases of development. ${ }^{1}$ Trials are also investigating convalescent plasma as a containment option or supportive therapy for patients with covid-19. ${ }^{2}$ Understandably, there is great public expectation that these efforts will be successful, but caution is necessary with respect to both vaccines and passive immunity.

\section{Vaccines}

Many candidate vaccines target the virus spike protein, a molecule essential for the virus to bind to the angiotensin converting enzyme 2 receptor complexes in the cell membrane as a first step for infection. ${ }^{3}$ Studies of SARS-CoV-2 genomic sequences indicate that regions encoding the receptor binding domain of the spike protein are highly conserved, providing hope for a successful vaccine directed at a stable target. However, substantial mutations (albeit rare) in the spike protein close to the receptor binding domain are described along with other drift variants. ${ }^{45}$ The effect of these mutations on protein expression and the antigenicity required to provoke an antibody response (or to interact with passive antibody) is unclear.

There are further reasons for caution over covid-19 vaccines. Over a decade, attempts to develop vaccines against SARS and MERS, caused by related coronaviruses, have been unsuccessful. ${ }^{6}$ Attempts to produce vaccines against other RNA viruses, such as dengue, resulted in candidates that were not protective, and some exacerbated disease through antibody dependent enhancement. ${ }^{7}$ Although there is no evidence that the SARS-CoV-2 vaccine candidates produce antibody dependent enhancement, it remains a possibility.

Furthermore, covid-19 disproportionately affects older age groups, where immune senescence leads to poorer quality immune responses. ${ }^{8}$ Vaccines may be less effective in those with greatest need. Additionally, infections with other coronaviruses and challenges with experimental vaccines have resulted in short term (1-2 years) protective immunity. ${ }^{6}$ Vaccine effectiveness and duration may therefore require repeated vaccinations and the use of adjuvants to improve responses.

\section{Antibody therapy}

Hyperimmune plasma and intravenous immunoglobulin infusions are safe and effective treatments for a wide range of human diseases. Convalescent blood was used in the 2014 Ebola epidemic in west Africa, when it improved survival compared with standard treatment. ${ }^{9}$ However, widespread immune dysregulation is a major contributor to the severest and most lethal expression of covid-19, ${ }^{10}$ including the cytokine storm syndrome-an overactive immune-inflammatory response to infection resulting in severe damage to tissues and organs. ${ }^{10-12}$ The timing of treatment with passive immune plasma is likely to be critical. Given at the wrong time in a patient's covid-19 trajectory, immune plasma could be ineffective ${ }^{2}$ or even enhance or induce a cytokine storm syndrome.

Early studies from Wuhan, China, documenting the clinical history of covid-19 patients along with serial analysis of their antiviral antibody responses, suggested that high levels of antibodies were an independent risk factor for severe disease or death. ${ }^{13} 14$ If so, treatment with immune plasma should probably occur early in the course of covid-19, ${ }^{2}$ before significant expression of inflammation-a possible harbinger of a cytokine storm.

An attractive alternative for exploiting passive immune therapy against SARS-CoV-2 is use of neutralising human/humanised monoclonal antibodies. Such antibodies can be cloned from the $B$ cell repertoire of recovered patients or be genetically engineered in the laboratory. Monoclonal antibodies can be produced rapidly, safely, and in large volumes with current technologies. However, once again, caution is needed, as monoclonals developed to treat severe influenza and respiratory syncytial virus infections failed to change the course of those diseases in clinical studies. ${ }^{15} 16$

Monoclonal antibodies are precisely focused on the neutralising sites on the spike protein of SARS-CoV-2 in contrast to the wide range of antibodies in convalescent plasma. Some plasma antibodies will be neutralising, but many others may have off-target effects, potentially contributing to tissue damage. For example, non-neutralising antibodies binding to non-spike protein viral antigens could result in damaging antibody reactions (type I-III) and antibody dependent disease enhancement. These adverse effects are less likely with the use of single or combinations of monoclonal antibodies, which are currently in early clinical studies. ${ }^{17} 18$ 
Finally, even if immunology yields excellent vaccines and antibody treatments to manage covid-19, by the time they are widely available the pandemic's human and economic cost will have been enormous. Therefore, immunological tools will at best complement public health vigilance, preparedness, and early control measures, which will remain vital for combating future potential pandemics.

Competing interests: The BMJ has judged that there are no disqualifying financial ties to commercial companies. The authors have no other interests. The BMJ policy on financial interests is here:

https://www.bmj.com/sites/default/files/attachments/resources/2016/03/16-current-bmj-educationcoi-form.pdf."

Provenance and peer review: Not commissioned; externally peer reviewed.

We thank Darreul Sewell for bringing to our attention preprints of the Wuhan antibody studies.

1 Caddy S. Developing a vaccine for covid-19. BMJ2020;369:m1790. doi: 10.1136/bmj.m1790 pmid: 32366511

2 Casadevall A, Pirofski LA. The convalescent sera option for containing COVID-19. J Clin Invest 2020;130:1545-8. doi: 10.1172/JCl138003 pmid: 32167489

3 Walls AC, Park YJ, Tortorici MA, Wall A, McGuire AT, Veesler D. Structure, function, and antigenicity of the SARSCoV-2 spike glycoprotein. Cell 2020;181:281-292.e6. doi: 10.1016/j.cell.2020.02.058 pmid: 32155444

4 LiX, Giorgi EE, Marichann MH, et al. Emergence of SARS-CoV-2 through recombination and strong purifying selection. bioRxiv 2020.03.20.000885. [Preprint.] 2020. doi: 10.1126/sciadv.abb9153. pmid: 32511348

5 Koyama T, Weeraratne D, Snowdon JL, Parida L. Emergence of drift variants that may affect covid-19 vaccine development and antibody treatment. Pathogens 2020;9: doi: 10.3390/pathogens9050324 pmid: 32357545

6 Padron-Regalado E. Vaccines for SARS-CoV-2: lessons from other coronavirus strains. Infect Dis Ther 2020:1-20. doi: 10.1007/s40121-020-00300-x. pmid: 32328406

7 Graham BS. Rapid COVID-19 vaccine development. Science 2020;368:945-6. doi: 10.1126/science.abb8923 pmid: 32385100

8 Aw D, Silva AB, Palmer DB. Immunosenescence: emerging challenges for an ageing population. Immunology 2007;120:435-46. doi: 10.1111/.j.1365-2567.2007.02555.x pmid: 17313487

9 Sahr F, Ansumana R, Massaquoi TA, etal. Evaluation of convalescent whole blood for treating Ebola virus disease in Freetown, Sierra Leone. J Infect 2017;74:302-9. doi: 10.1016/j.jinf.2016.11.009 pmid: 27867062

10 Blanco-Melo D, Nilsson-Payant BE, Liu WC, etal. Imbalanced host response to SARS-CoV-2 drives development of covid-19. Cell 2020;181:1036-1045.e9. doi: 10.1016/j.cell.2020.04.026 pmid: 32416070

11 Mehta P, McAuley DF, Brown M, et al; HLH Across Speciality Collaboration. UKCOVID-19: consider cytokine storm syndromes and immunosuppression [Letter]. Lancet 2020 doi: 10.1016/S0140-6736(20)30628-0.

12 José RJ, Manuel A. COVID-19 cytokine storm: the interplay between inflammation and coagulation. Lancet Respir Med 2020;8:e46-7. doi: 10.1016/S2213-2600(20)30216-2 pmid: 32353251

13 Zhao J, Yuan Q, Wang H, etal. Antibody responses to SARS-CoV-2 in patients of novel coronavirus disease 2019. Clin Infect Dis2020: [Epub ahead of print]. doi: 10.1093/cid/ciaa344 pmid: 32221519

14 Hou H, Wang T, Zhang B, etal. Detection of IgM and IgG antibodies in patients with coronavirus disease 2019. Clin Transl Immunology 2020;9.. doi: 10.1002/cti2.1136 pmid: 32382418

15 Alansari K, Toaimah FH, Almatar DH, El Tatawy LA, Davidson BL, Qusad MIM. Monoclonal antibody treatment of RSV bronchiolitis in young infants: a randomized trial. Pediatrics 2019;143: doi: 10.1542/peds.2018-2308 pmid: 30760509

16 Beigel JH. Polyclonal and monoclonal antibodies for the treatment of influenza. Curr Opin Infect Dis 2018;31:527-34. doi: 10.1097/QC0.0000000000000499 pmid: 30299360

17 Liu A. Regeneron scales up manufacturing, eyes human tests of COVID-19 antibody cocktail in June. Fierce Pharma, 5 May 2020. https://www.fiercepharma.com/pharma/regeneron-scales-upmanufacturing-eyes-human-tests-covid-19-antibody-coktail-june

18 Lilly begins world's first study of a potential covid-19 antibody treatment in humans. Press release, 1 Jun 2020 https://investor. lilly.com/news-releases/news-release-details/illy-begins-worlds-firststudy-potential-covid-19-antibody

This article is made freely available for use in accordance with BMJ's website terms and conditions for the duration of the covid-19 pandemic or until otherwise determined by BMJ. You may use, download and print the article for any lawful, non-commercial purpose (including text and data mining) provided that all copyright notices and trade marks are retained. 